\title{
The Effect of Vocational High School Administrators' Leadership Behaviors on Teacher Job Satisfaction
}

\author{
Said Taş \\ Faculty of Education, University of Süleyman Demirel, Turkey
}

Copyright $\subset 2017$ by authors, all rights reserved. Authors agree that this article remains permanently open access under the terms of the Creative Commons Attribution License 4.0 International License

\begin{abstract}
The purpose of this research is to determine the effect of vocational high school administrators' leadership behaviors on teacher job satisfaction. The study group of the research consists of 21 technical teachers who work at vocational high schools in the city of Isparta. The data obtained have been analyzed by calculating the frequency, arithmetic mean, correlation and regression analyses. The vocational high school administrators exhibit all types of behaviors in every dimension of leadership at the level of "frequently". It has been understood that there is a significant correlation between the dimensions of administrators' leadership behaviors and teacher job satisfaction. Another considerable finding of the research is that the effect of individual-oriented leadership behaviors - one of the dimensions of leadership behaviors- on teacher job satisfaction is higher than the effects of other dimensions of leadership behaviors.
\end{abstract}

Keywords Leadership, Leadership Behaviours, Job Satisfaction

\section{Introduction}

In the $21^{\text {st }}$ century, in which there is a competitive atmosphere, job satisfaction and leadership have become important issues for the education institutions that work with the intention of productivity and quality. Effective leaders and workplace have significant roles in the attainment of the objectives. At schools, school administrators are the ones who are primarily considered as leaders. An administrator is someone who organizes, leads, coordinates, influences, and controls the employees at schools in order to achieve the goals [1]. Another important thing is the performance of those who work with the leader, namely, teachers. Studies in recent years show that job satisfaction has a relationship with the performance of teachers at schools.

Besides being a multi-dimensional concept, job satisfaction can simply be defined as "the extent to which employees like their jobs". Job satisfaction is an emotional reaction from the employee to the business statement. Accordingly, it cannot be seen, it can only be expressed $[2 ; 3$; $4 ; 5 ; 6 ; 7 ; 8 ; 9 ; 10]$. Job satisfaction is the reflection of the employee's emotional reaction to the job or to its certain aspects $[11 ; 12]$. The financial gain of the job, the level of employee satisfaction with the co-workers and the sense of happiness stemming from producing something are the signs of job satisfaction. This feeling makes the individual internally happy. Due to its being an emotional reaction, it is an abstract concept and a difficult term to measure. The signs of job dissatisfaction can be useful for understanding job satisfaction. Job dissatisfaction is reflected as behaviors, such as; reluctance to work, escaping from work, being absent from work, or leaving the work. While job satisfaction regulates the employee's social, physiological, and psychological health, the contrary situation leads to various unhealthy situations. When considered from institutional point of view, job dissatisfaction is most obviously reflected as productivity loss. Behaviors like slowdown of work, increase in absenteeism and occupational accidents, deterioration of work discipline, careless consumption of sources, increase in employee complaints, etc. are some other signs [13]. According to [14], job satisfaction is the variation between what employees expect from the job and co-workers, and how they perceive the job and co-workers. Meeting employees' expectations from work both increases job satisfaction and gives rise to achieve the goals in a more productive way.

For the effectiveness of institutions, school administrators should pay regard to all kinds of factors that may have an effect on productivity in a positive or a negative way. Just like in educational institutions, in-public utility institutions, the achievement level of institutional, individual and interchangeable goals plays an important role in job satisfaction of employees. The reason is that job satisfaction increases and decreases depending on the extent to which the organization fulfils employee needs and expectations.. The extent to which the organization fulfils employee needs and expectations is -on a large scale-- related to the leadership behaviors shown by the managers. Researchers assert that 
leadership behaviors shown by the managers are the most significant factors of all essential factors that affect employee job satisfaction and complaints $[15 ; 16 ; 17]$.

It seems that the concept of leadership in management emerged in the1960s for the first time. Leadership is a process which includes states like willingness, faith, commitment, voluntariness. In this process, many sources of power integrate and there exists an effect transforming the difficulties stemming from this integration into willingness, faith, commitment, and voluntariness [18]. A leader is someone who reveals the unapparent common thoughts and wills as an adopted goal and potentizes the members' secret power in accordance with this goal [19]. In the process of leadership, there is a leader and there are followers. The concept of "followers" evokes a passive behavior and commitment to the leader. However, today, in leadership approaches, a multidirectional communication between leader and followers has been emphasized [20]. Leadership is a concept analyzed and defined from different perspectives in various ways. In this case, leadership is a matter of management science and is a concept that can be addressed and analyzed in psychological, sociological, political and philosophical aspects as well as being related to occupational life [21]. Leadership has generally been defined in terms of personal characteristics, leadership behaviors, interaction model, role relations, perceptions of followers, the influence on followers, and its effect on the organizational culture. The definitions mostly emphasize a process of influence. However, in most of the definitions there is no common point or suggestion; nevertheless, they differ from one another in many aspects. Some of those differences are the use of influence and the person who influences, influence, leadership styles and organizational commitment, the attitudes and behaviors concerning the use of influence [22].

Leadership approaches have been examined in the related literature as four groups; approach of traits, behavioral approach, situational approach and modern approach [23]. According to the approach of traits, the leader is different from the followers in the aspects of his/her personal traits, individual talents, and physical properties [24] and this difference is the essential reason for his/her becoming a leader. However, while showing different leadership behaviors in similar settings can easily be explained by the approach of traits, the situation in which leaders having the same personality structure show different behaviors in different settings has become difficult to explain by means of this approach. This approach has been inadequate to explain the difference between leaders and non-leaders, and studies on leaders' behaviors have begun to emerge.

Studies conducted by behaviorists on the differences among leader behaviors have made behavioral approach a current issue. According to the behavioral approach, the leader's behaviors and the employees' maturity level determine the leader's effectiveness [25]. [26] Referring to the studies conducted by Ohio University, a leader has two types of behavior which are individual-oriented and institutional-oriented. The dimension in which the individual is taken into consideration includes such leadership behaviors as sense of mutual trust in interpersonal relations, solidarity, helping each other, and understanding the opinions and feelings of followers and showing respect. As for the institutional dimension, there are such leadership behaviors as putting institutional goals forward, fulfillment of reciprocal duties and responsibilities by the leader and followers, and enacting the whole team.

In the study conducted by Rensis Likert and his colleagues at the University of Michigan, two different leadership behaviors which are institution-oriented and individual-oriented have been prescribed [24]. While an institution-oriented leader shows such behaviors as drawing his/her strength from his/her position and controlling whether the followers fulfill their designated duties and responsibilities, exhibiting chastising and authoritative behaviors when necessary, an individual-oriented leader shows such behaviors as predicating delegation on, taking followers' personal growth and progression into consideration, prioritizing their happiness. It has been concluded that in the institutions managed by individual-oriented leaders, the levels of morale and success of the followers and productivity are high; as for the institutions managed by institution-oriented leaders, there is the exact opposite situation [27].

Since 1960s, together with leadership behaviors, the environmental features affecting those behaviors have been emphasized and "the contingency approach in leadership" has shown up. In this approach, it has been argued that there are no types of leadership which can be valid and effective in all circumstances [25]. A leader, in certain conditions and situations, can sometimes exhibit institution-preferred behaviors, sometimes individual-preferred behaviors, sometimes democratic behaviors, and sometimes autocratic behaviors [28]. According to this approach, just as there are no types of management that can be the best all the time and in all settings, there is no institutional structure that can be valid all the time and in all settings. In other words, a leader's behaviors depend on the situation.

In parallel with developments in the field of management science, studies on leadership issue have revealed some different initiatives besides the traditional approaches. These perspectives, which can be called modern approaches, [29] have included some new leadership styles in the literature of management science. According to [24], concepts like transformation, development, consolidation, vision and social responsibilities are at the bottom of these perspectives. Unlike the traditional approaches, modern approaches include types of behaviors that are oriented to the future, innovation, change, and reforms. In this new leadership approaches, the quality of the communication between the leader and followers is of capital importance.

\section{Leadership Behaviors and Their Effects on Employees}

Leadership behaviors have primarily been considered as 
two-dimensioned, institution-oriented leadership behaviors and individual-oriented leadership behaviors. In the later years, change-oriented leadership behavior, which is regarded as one of the modern approaches, has emerged. An institution-oriented leader exhibits some typical behaviors such as; prioritizing necessary duties, oppressing the employees for them to do their duties, frequently controlling whether the duties are done, focusing on principles rather than relations, and regarding the employees as a means of fulfilling the duties. As for the individual-oriented leadership behaviors, these behaviors prioritize morale and motivation, success, job satisfaction and happiness of employees, besides the institutional goals. In change-oriented leadership behaviors, flexibility in perspectives on incidents, creating opportunities for development and participation are the essentials. Leadership behaviors should not be regarded as a certain preference among the approaches mentioned above. There is no type of leadership behavior which is guaranteed to be successful in all circumstances. Although individual-oriented leadership behaviors make the employees achieve high satisfaction level in some circumstances, some leadership behaviors placing importance on the individual and change can supply higher satisfaction level in some institutions.

When a leader doing his/her leadership job, which type of leadership behaviours (individual-oriented or change-oriented) he/she exhibits depends on the organizational structure, the scope, activity diversity, and environmental problems $[30 ; 31 ; 32]$. As it has been indicated by [24], a leader can sometimes exhibit institutional priority behaviors, sometimes individual priority behaviors, sometimes democratic, sometimes autocratic behaviors depending on the setting and conditions. In addition, in institutions with high level of productivity, the leader can integrate the institution-oriented and individual oriented behaviors. What matters here is the leader's ability to use available resources, primarily human resources, to achieve their goals. Many researches that investigate the effects of leadership behaviors on job satisfaction have important places in the literature. The most important ones of those researches have been conducted with [16] healthcare staff [33], university instructors, [34] and [35] primary school teachers. These investigations have emphasized the importance of managing individual or change-oriented leadership behaviors in corporate goals. In the vocational high schools which are production-oriented educational institutions, it is expected that the institutional aims are important, but the educational institutions are always in favor of the individuals and the change in priority. The vocational high schools that are interested in every part of the society also have the input, the processing, the output, the raw material. Teachers have a direct influence on students and they are functioning. Teachers directly influence the achievement of the institutional objectives at the desired level by means of their knowledge, skills and attitudes. This requires school administrators to be more responsive to teachers' job satisfaction. The effects of managers' leadership behaviors on teachers have been examined at various stages of education, but vocational schools have not sufficiently taken into account in the researches. Therefore, in this research, the aim is to determine the leadership behaviors of vocational high school administrators on the job satisfaction of technical teachers.

\section{Method}

This research is a descriptive study carried out through the survey model. The sample of the study is composed of all the technical teachers working in the vocational high schools in Isparta. Vocational high schools can be defined as educational institutions that provide vocational training in industrial technical fields together with general cultural courses aiming to provide a common general culture at secondary level.

As a data collection tool, "leadership behavior" and "job satisfaction" scales were developed. Benefiting from the survey questions used in previous studies $[36 ; 14 ; 37]$, an item pool was established; 98 items were related to leadership behaviors, 62 items were related to job satisfaction. The selected participants from the study group were requested to code the items as positive, negative and none. Questions that most participants did not classify positively or negatively were removed from the item pool. After this extraction, the remaining questions were revised in line with expert opinions and the scale was developed. A 5-point Likert type scale was used to measure the scale items. Factor and reliability analyses were performed for construct validity of the measurement tool. The suitability of the data for factor analysis was examined by the Kaiser-Meyer-Olkin $(\mathrm{KMO})$ coefficient and the Barlett test. $\mathrm{KMO}=0.931$ and Barlett test score $=4008.61$ were found for the leadership behaviors of the scale. On job satisfaction part of the scale, $\mathrm{KMO}=0.926$ and the Barlett test value is 2118.51. Dimensions of managerial leadership behaviors of the scale were called; Institution-oriented leadership behaviors, individual-oriented leadership behaviors, and change-oriented leadership behaviors [14]. The first dimension of the scale, leadership behaviors consisted of 10 items as "institution-oriented" leadership behaviors, the second dimension consisted of 14 items as individual-oriented leadership behaviors and the third dimension consisted of 11 items as change-oriented leadership behaviors. The job satisfaction part of the scale is one-dimensional and consists of 19 items. The factor load values of the institution-oriented leadership behavior dimension of the "leadership behaviors of managers" section of the scale ranges from 0.63 to 0.84 . The variance load value is 0.64 . The factor load values of the change-oriented leadership behavior dimension range from 0.66 to 0.87 and the variance load value is 0.66 . The factor load values of the individual-oriented dimension range from 0.72 to 0.92 and 
the variance load value is 0.71 . Factor load values of the "job satisfaction" section of the scale are between 0.61 and 0.87 and the variance load value is 0.61 . The reliability of data collected through the scale was tested by means of Cronbach Alpha coefficient. As a result of the analysis, the Cronbach Alpha value of the leadership section is 0.97 and the Cronbach Alpha reliability value of the job satisfaction section is 0.98 . In the collection and analysis of the data, 151 teachers of the total 160 technical teachers were subjected to the survey by the researchers and their assistants with representative power [3], with 3\% sampling error. However, 121 scales were subjected to analysis. The frequency and percentage values of the demographic variables were determined in order to obtain a general view of teachers' personal information in the research. Then, the arithmetic mean and standard deviations of the answers given to the scale were calculated and the level of leadership behaviors of the vocational high school administrators was determined. A correlation analysis was conducted to determine the direction and degree of the relationship between leadership behaviors and job satisfaction. The effect of leadership behaviors on job satisfaction was examined by regression analysis and significance was tested at the level of 0.05 .

\section{Findings and Interpretations}

In this section, the findings of the research were included. Frequency and arithmetic averages of scaled responses were calculated to determine the extent to which vocational high school administrators performed institution -oriented, individual-oriented and change-oriented leadership behaviors, and the significant ones of these values are given in Table 1.

As seen in Table 1, the overall average of institution-oriented leadership behaviors was found as $(\bar{X}=$ 3.58). According to this finding, it can be said that vocational high school administrators use leadership oriented behaviors "mostly". When looking at the levels of leadership behaviors that constitute this dimension, the item "attaches importance to the rule" takes place on the top with $(\bar{X}=4,0)$; the item "inform" takes the last place in the order with $(\bar{X}=3,10)$. When the same table was examined, it was found that the general average of individual-oriented leadership behaviors is $(\bar{X}=3,63)$. According to this result; it seems that vocational high school administrators "often" show individual-oriented leadership behaviors. When looking at the levels of leadership behaviors that constitute this dimension, the item "the mistakes are seen as an opportunity to learn" takes place on the top with $(\bar{X}=3,91)$; the item "exhibits fair behaviors" takes the last place with $(\bar{X}=3,42)$. The fact that the level of vocational high school administrators' individual-oriented leadership behaviors is at a high average is an indicator showing that the vocational high school administrators perform a modern management. It is institutionally important for the vocational high school administrators to show leadership behaviors that attach importance to teachers.

Table 1. The extent to which vocational high school administrators show Leadership Behaviors

\begin{tabular}{|c|c|c|c|c|}
\hline Dimension & & $\mathbf{N}$ & $\square$ & $\mathbf{S}$ \\
\hline \multirow{11}{*}{ Institution-oriented Leadership Behaviors } & 1. Attaches importance to the rules & 1,21 & 4,01 & 1,14 \\
\hline & 2. Emphasizes work supervision & 1,21 & 3,96 & 1,07 \\
\hline & 3. Provides source. & 1,21 & 3,71 & 1,16 \\
\hline & 4. Exhibits transparent management & 121 & 3,60 & 1,27 \\
\hline & 5. Has a developed accountability & 121 & 3,57 & 1,26 \\
\hline & 6. Consistent in practice & 121 & 3,55 & 1,31 \\
\hline & 7. Cares about the institutional culture & 121 & 3,50 & 1,36 \\
\hline & 8. Cares about team work & 121 & 3,43 & 1,22 \\
\hline & 9. Include teachers in decision making & 121 & 3,40 & 1,13 \\
\hline & 10. Informs & 121 & 3,10 & 1,33 \\
\hline & Total & 121 & $\mathbf{3 , 5 8}$ & 1,23 \\
\hline
\end{tabular}


Table 1. The extent to which vocational high school administrators show Leadership Behaviors (Cont.)

\begin{tabular}{|c|c|c|c|c|}
\hline Dimension & & $\mathbf{N}$ & $\bar{X}$ & $\mathbf{S}$ \\
\hline \multirow{11}{*}{$\begin{array}{l}\text { Individual-oriented Leadership } \\
\text { Behaviors }\end{array}$} & 1. Sees the mistakes as an opportunity to learn & 121 & 3,91 & 1,27 \\
\hline & 2. Shows respect & 121 & 3,78 & 1,17 \\
\hline & 3. Appreciates good work. & 121 & 3,76 & 1,33 \\
\hline & 4. Trusts teachers & 121 & 3,74 & 1,25 \\
\hline & 5. Shows affinity and tolerance & 121 & 3,62 & 1,19 \\
\hline & 6. S/he is trustworthy & 121 & 3,57 & 1,28 \\
\hline & 7. Create a friendly environment & 121 & 3,55 & 1,43 \\
\hline & 8. Provides an opportunity for development & 121 & 3,52 & 1,32 \\
\hline & 9. Cares about rights & 121 & 3,47 & 1,40 \\
\hline & 10. Exhibits fair behaviors & 121 & 3,42 & 1,30 \\
\hline & Total & 121 & 3,63 & 1,29 \\
\hline Dimension & & $\mathbf{N}$ & $\bar{x}$ & $\mathbf{S}$ \\
\hline \multirow{11}{*}{ Change-oriented Leadership Behaviors } & 1. Makes plans for the future & 121 & 3,95 & 1,18 \\
\hline & $\begin{array}{l}\text { 2. Supports new and different ideas in the } \\
\text { implementation of jobs }\end{array}$ & 121 & 3,65 & 1,09 \\
\hline & 3. Decides quickly & 121 & 3,62 & 1,11 \\
\hline & 4. Respects different views & 121 & 3,61 & 1,27 \\
\hline & 5. Develop different ideas & 121 & 3,58 & 1,13 \\
\hline & 6. $\mathrm{S} /$ he is open to change & 121 & 3,57 & 1,17 \\
\hline & $\begin{array}{l}\text { 7. Use brainstorming methods frequently to } \\
\text { solve problems }\end{array}$ & 121 & 3,56 & 1,26 \\
\hline & 8. Tries new ways in problem solving & 121 & 3,54 & 1,17 \\
\hline & 9. S/he does not avoid taking risks & 121 & 3,41 & 1,33 \\
\hline & 10. $\mathrm{S} / \mathrm{he}$ is open to criticism & 121 & 3,28 & 1,30 \\
\hline & Total & 121 & 3,57 & 1,22 \\
\hline
\end{tabular}

Table 2. The relationship between Leadership Behaviors and Job Satisfaction

\begin{tabular}{|c|c|c|c|c|}
\hline & & $\begin{array}{c}\text { Institution-oriented } \\
\text { Leadership Behaviors }\end{array}$ & $\begin{array}{c}\text { Individual-oriented } \\
\text { Leadership Behaviors }\end{array}$ & $\begin{array}{c}\text { Change-oriented Leadership } \\
\text { Behaviors }\end{array}$ \\
\hline \multirow{3}{*}{ JOB SATISFACTION } & Pearson Correlation & $.739^{* *}$ & $.776^{* *}$ & $.737^{* *}$ \\
\cline { 2 - 5 } & $\mathrm{P}$ & 0.00 & 0.00 & 0.00 \\
\cline { 2 - 5 } & $\mathrm{N}$ & 121 & 121 & 121 \\
\hline
\end{tabular}

${ }^{*} \mathrm{p}=0.05$ significance level

$* * \mathrm{p}=0.01$ significance level

According to Table 1, vocational high school administrators also use change-oriented leadership behaviors "often" with $(\bar{X}=3,57)$ as behaviors in the other dimensions. When we look at the extent to which they exhibit the leadership behaviors in this dimension, while the item "makes plans for the future" takes place on the top $(\bar{X}=3,95)$, "open to criticism" takes the last place with $(\bar{X}=3,28)$. In the research, a correlation analysis was performed to determine whether there was a significant relationship between leadership behaviors and teacher job satisfaction, and the findings of this analysis are given in Table 2.

When Table 2 is examined, it is seen that the relationship among all dimensions of leadership behaviors and teacher job satisfaction is positive and high. However, while the highest relationship level was found with the individual-oriented leadership behaviors $(\mathrm{r}=0.776, \mathrm{p}<0.01)$, the lowest relationship level was found with the change-oriented leadership behaviors $(\mathrm{r}=0.737, \mathrm{p}<0.01)$. According to these findings, individual-oriented leadership behaviors cause teachers to be more satisfied with their job.

The effect of leaderhsip behaviors of vocational high school administrators on teacher job satisfaction was examined by regression analysis. Leadership behaviors dimensions were taken as variables to determine manager leadership behaviors dimensions affecting job satisfaction. The results of regression analysis of these analyzed variables are given in Table 3 . 
Table 3. The results of regression analysis regarding the effect of manager leadership behaviors on teacher job satisfaction

\begin{tabular}{|c|c|c|c|c|c|c|c|}
\hline Variable & $\mathrm{B}$ & Standard Error & $\mathrm{B}$ & $\mathrm{T}$ & $\mathrm{P}$ & Binary r & Partial R \\
\hline Stable &, 81 & .221 & - & 3,89 & .001 & - & - \\
\hline Institution-oriented Leadership Behaviors &, 12 &, 156 &, 513 &, 66 &, 501 &, 739 &, 067 \\
\hline Individual-oriented Leadership Behaviors &, 46 &, 192 &, 514 & 2,40 &, 016 &, 777 &, 238 \\
\hline Change-oriented Leadership Behaviors &, 13 &, 178 &, 167 &, 76 &, 443 &, 761 &, 077 \\
\hline
\end{tabular}

$\mathrm{R}=0.782, \mathrm{R}^{2=} 0.61 \mathrm{~F}=(3,96)=50,22, \mathrm{p}=.000$

According to the findings in Table 3 , it can be pointed out that the variables of individual-oriented, change-oriented, and institution-orientedleadership behaviors of vocational high school administrators have significant effects on teachers' job satisfaction $(\mathrm{R}=0,783, \mathrm{R} 2=0.61 \mathrm{p}<.01)$. These variables account for about $61 \%$ of the variance in teacher job satisfaction.

Relative significance order of the predictor variables over the job satisfaction according to the standardized regression coefficient $(\beta)$ is as; individual-oriented leadership behaviors, institution-oriented leadership behaviors, and change-oriented leadership behaviors. When the results of the t-test on the significance of the regression coefficients are examined, it is seen that "institution-oriented leadership behaviors" are important predictors of teacher job satisfaction. On the other hand, it is seen that the variables of change-oriented and institution-oriented leadership behaviors do not have a significant effect on teachers' job satisfaction.

\section{Conclusions and Recommendations}

According to the research findings, vocational high school administrators use all three leadership behaviors "most of the time". It can be said that administrators shows all three leadership behaviors, however they show more individual-focused leadership behaviors than other two leadership behaviors that were found in the study. The results of this research coincide with [39; 40]'s reseach results. Managing the vocational high schools with an individual-oriented management approach will affect the job satisfaction in a positive way. The happiness of the teachers in the educational environment will be reflected positively to the student-teacher relationship and the productivity of the education will increase. The fact that the psychological, sociological and economic needs of the teachers, the most important constituent of education, are taken into account by the administrators is also a positive development in terms of the future of vocational high schools [41].

In the research, the institution-oriented leadership behaviors of vocational high school administrators was higher than the rest of the leadership behaviors. This ratio also indicates that vocational high school administrators cares about their institutions as much as they care about their employees. This result is similar to the research conducted by [42] on university administrators' leadership behaviors. In that vein, in the research conducted by[43; 39] institution-oriented leadership behaviors were found meaningful in job satisfaction, which is consistent with the results of our research. As is known, job satisfaction is a feeling that is experienced when the work of the employee and what s/he has achieved jibe with his/her needs and personal values [44]. Job satisfaction may vary depending on the person's priorities and expectations. Even the same person may have different satisfactions at different times depending on such factors as job change, promotion, changes in the lifestyle, changes in the country's economy [45; 46; 47; 48].The high level of institution-oriented leadership behaviors of high school administrators may also be due to the fact that the unemployment rate in Turkey is $13.7 \%$ [49], and also because teachers can push some of their needs into the background and are happy to have a job. Taking all of these into account, it is normal to have such results.

In the research, the fact that vocational high school managers show change-oriented leadership behaviors with $(\bar{X}=3.57)$ is not an expected result because the basic function of vocational high schools, which produces the qualified human power needed by the country besides being known to have a significant influence on society, is not limited to transferring knowledge, conducting corporate activities and meeting the needs of the individual. To serve for the society, to lead $[50 ; 51]$, to become a means of production, and to focus on the development and transformation of human resources are among the duties of these institutions. For this reason, vocational high school managers are expected to exhibit change-oriented leadership behaviors as much as individual-oriented leadership behaviors. However, the results of the survey did not appear as expected. Research [53; $54 ; 55 ; 26 ; 56 ; 57 ; 58 ; 35]$ results show that leadership behaviors that are mostly exhibited by principals are in the dimension of change-oriented leadership behaviors. In addition, that the school administrators mostly exhibit change-oriented behaviors has been found to be as a positive development. As indicated by [59], change-oriented leaders do not regard every teacher as having similar characteristics, but as a separate personality. The leadership competencies of vocational high school administrators should be high in the sense of focus on change. Because the technical teachers who work in the vocational high school make a difference in the personality traits by making more use of the technology and the hand skills.Because, the technical teachers who work in the vocational high schools make different use of the personality traits by making more use of the technology and hand skills.

It is unlikely that vocational high school administrators will be able to carry out change-oriented leadership behaviors at the desired level, since they have been 
nominated without having received an undergraduate or master's degree in the field of educational administration and without investigating whether they have change provider characteristics. The reason is that management is regarded as a field of science although it is used to be regarded as an art in the past [61] [62]. It is a recognized fact that leadership behaviors can be taught to persons through education and the changes desired in these behaviors can be made $[63 ; 64]$. People are not created innately as good managers, but management art and knowledge are gained only through learning [65]. In order to develop their vocational high schools, they have revealed in their research that vocational high school administrators should be given a serious training in educational leadership and management of school organizaitons[66]. We can build up the vocational high schools that will accelerate social change with the construction of strong school administrations that can lead change and development. [67] Therefore, school administrators should be trained in educational management field and carry leadership qualities personally. In addition, it should not be forgotten that the nature of the purpose to be achieved, the talents and expectations of employees, the characteristics of the organization, and the experiences and personality traits of leaders and followers also have significant influences on school administrators' leadership styles.

Although vocational high school administrators are expected to exhibit mostly "change-oriented leadership behaviors", that the results of the individual-oriented, institution-oriented and change-oriented leadership behaviors are close to each other is also important. Because different conditions require different styles of leadership. There is no single and best leadership style for any situation or institution. The style of leadership may vary depending on circumstances [70; 71]. In this regard, the results of this research support the idea that the leader is created by the leadership environment and leadership behaviors may vary depending on the characteristics and requirements of the environment [72]. The presence of educational environments in the vocational high school will reduce the differences in the behaviors of the administrators so that the level of teacher job satisfaction will increase.

Research conducted show that there is a meaningful relationship between leadership behaviors and job satisfaction $[73 ; 74 ; 75 ; 76 ; 77 ; 39 ; 78 ; 14 ; 79 ; 33]$. There are also studies in the literature having found that there is no relationship between individual-focused leadership behaviors and job satisfaction [80]. Although the relationship between leadership behaviors and job satisfaction was found in research, the highest relationship was found mostly between individual-focused leadership behaviors and job satisfaction. As a result; when the literature on educational management is examined, it is seen that the issue of leadership and job satisfaction is very wide. The main reason underlying the efforts of scientists to determine the leadership behaviors of contemporary school administrators is that administrators are the most important constituents in creating a contemporary, effective school [81]. The role of the administrators in teacher training is also important in terms of seeing the failures in-situ, the continuous involvement in the school system, which are the most basic unit of educational services, and being a bridge between theory and practice [82]. There are different views on leadership behaviors that school administrators should have. However, as emphasized in this research, the most widely accepted ones are individual-oriented and change-oriented leadership approaches. When the related literature is examined, it is seen that especially individual-oriented and change-oriented leadership behaviors are highly effective leadership styles in the dimensions of organizational commitment, job satisfaction, performance etc. According to the findings of this research, there is an important relationship between individual-oriented leadership behaviours and teachers' job satisfaction. As the leadership behaviors of vocational high school administrators approach towards individual-oriented leadership behaviors from institution-oriented leadership behaviors, teacher job satisfaction level increases. For this reason, it is important for school administrators to be aware and educated about individual-oriented leadership behaviors in order to increase the organizational commitment of employees.

Researchers can contribute to better understanding effect of administrators' leadership behaviors on teachers' job satisfaction by also doing quantitative and qualitative researches on administrators of preschool, primary school, junior high school, general high schools.

\section{REFERENCES}

[1] Gürsel, M. (1997). Okul yönetimi. Konya.Mikro Yayınları.

[2] Çetinkanat, C. (2000). Örgütlerde güdülenme ve iş doyumu. Ankara. Anı Yayıncılık.

[3] Karaköse, T., Kocabaş, İ. (2006). Özel ve devlet okullarında ögretmenlerin beklentilerinin iş doyumu ve motivasyon üzerine etkisi. Eğitimde Kuram ve Uygulama Dergisi, 2(1), $3-14$.

[4] Erdoğan, İ. (1999). İşletme yönetiminde örgütsel davranış. İstanbul: Dönence Basım ve Yayın Hizmetleri.

[5] Avşaroğlu, S., Deniz, M.E., Kahraman, A. (2005). Teknik Öğretmenlerde Yaşam Doyumu İş Doyumu ve Mesleki Tükenmişlik Düzeylerinin İncelenmesi. Selçuk Üniversitesi Sosyal Bilimler Enstitüsü Dergisi, 14, 115-129

[6] Acar, E. (2007). Uzmanlık Alanında Çalışmanın İş Doyumuna Etkisi. Paradoks, Ekonomi, Sosyoloji ve Politika Dergisi, y1l 3,(1)

[7] Luthans, F. (1995). Organizational Behavior. New York: Mcgraw Hill Book Company,

[8] Balc1, A. (2006). Sosyal Bilimlerde Araştırma Yöntemler Teknikler İlkeler. Ankara: Pegem Yayıncılık 
[9] Hecht, M. L. (1978c). "The Conceptualization and Measurement of İnterpersonal Communication Satisfaction. Human Communication Research, 4 (3), 253-264.

[10] Mottaz, C. (1986). Gender differences in work satisfaction, work-related rewards and values, and determinants of work satisfaction. Human Relations, 39(4), 359-378.

[11] Oshagbemi, T. (2000). Gender Differences in The Job Satisfaction of University Teachers. Women in Management Rewiev, 15 (7), 331- 343

[12] Yüksel, İ (2002). Bilgisayar işletmelerinin Öznel Yorgunluk Belirtileri İle İş Doyumu ve Örgütsel Bağlılık Arasındaki İlişkinin Analizi, Hacettepe Üniversitesi. İ.İ.B.F. Dergisi. 19 ( 2 ) .143- 157.

[13] Bozkurt, Ö., Bozkurt, İ. (2008). İș Tatminini Etkileyen İşletme İçi Faktörlerin Eğitim Sektörü Açısından Değerlendirilmesine Yönelik Bir Alan Araştırması, Doğuş Üniversitesi Dergisi, 9 (1), 1-18

[14] Tengilimoğlu, D. (2005). Hizmet işletmelerinde liderlik davranışları ile iş doyumu arasındaki ilişkinin belirlenmesine yönelik bir araştırma. GazI Üniversitesi Ticaret ve Turizm Eğitim Fakültesi Dergisi, (1), 23-45.

[15] Akıncı, Z. (2002). Turizm sektöründe iş tatminini etkileyen faktörler: beş yıldızlı konaklama işletmelerinde bir uygulama. Akdeniz Üniversitesi İ.İ.B.F Dergisi, 4, 1-25

[16] Vural, G., Eroğlu, K. Ve Kavuncubaşı, Ş. (1999). Hemşirelikte önderlik davranışı ve iş doyumu. Modern Hastane Yönetimi Dergisi, 3(3), 14-17.

[17] Likert, R. (1961). New patterns of management. New York: McGraw Hill Book Company.

[18] Erçetin, Ş.Ş.(2000). Lider sarmalında vizyon. Ankara: Nobel Yayınları.

[19] Celep, C.(2004). Dönüşümsel liderlik. Ankara: Anı Yayıncilik.

[20] Çelik, V. (2005). Liderlik. (Edt.Özden,Y.) Eğitim ve okul yöneticiliği el kitabı. Ankara: PegemA Yayıncılık.

[21] Şişman, M. (2015). Öğretim liderliği. 4. Baskı. Ankara: PegemA Yayınları.

[22] Yukl, G.(1989). Managerial leadership: a review of theory and research. Journal of Management, 15 (2), 251-289.

[23] Eryılmaz, F.(2006). Endüstri meslek lisesi okul müdürlerinin dönüsümcü liderlik özelliklerine sahip olma düzeyleri. (Ankara İli Örneği). Yayımlanmamış Yüksek Lisans Tezi. G.Ü, Eğitim Bilimleri Enstitüsü, Ankara.

[24] Aksel, İ. (2003). İşletme yöneticilerinin liderlik davranışlarının iş tatmini üzerine etkileri ve bir uygulama. Pamukkale Üniversitesi, Denizli: Yayımlanmamış Yüksek Lisans Tezi

[25] Çelik,V. (2014). Eğitimsel liderlik. Ankara: Pegem Akademi Yayıncilik

[26] Eren, E. (2015). Yönetim ve organizasyon. İstanbul: Beta Basım Yayım Dağıtım A.Ş.

[27] Hodgetts, R. M. (1990). Management (theory, process and practise). Çev. Canan, Çetin \& Esin C., Mutlu, 5. Basım, İstanbul: Der.

[28] Mathews, B.P. ve Shepherd, J.L.(2002). Dimensionality of
Cook and Wall's (1980) British Organizational Commitment Scale. Journal of Occupational and Organizational Psychology. 75,

[29] Serinkan, C., Bardakçı, A. (2007). Pamukkale üniversitesinde çalışan öğretim elemanlarının iş tatminlerine ilişkin bir araştırma. Karaman İ̈BF Dergisi, (12).

[30] Tekarslan, E. (1989). Sosyal psikoloji. İstanbul: Filiz Kitapevi.

[31] Szilagyi, A. (1990). Organization behaviour, New York:Harper Collins Pub. Co.

[32] Doğan, S. (2001). Liderlik mi? yöneticilik mi? geleneksel liderlik davranış tarzları ve bu konudaki yeni yaklaşımlara bir bakış. Atatürk Üniversitesi, İ.İ.B.F. Dergisi, 15 (3-4).

[33] Akdoğan, E. (2002). Öğretim elemanlarının algıladıkları liderlik stilleri ile iş doyumu düzeyleri arasındaki ilişki. Yayımlanmış Yüksek Lisans Tezi, Marmara Üniversitesi, İstanbul.

[34] Karadă̆, E., Başaran, A., \& Korkmaz, T. (2009). İlköğretim okulu ögretmenlerinin algıladıkları liderlik biçimleri ile iș doyumları arasındaki ilişki. Balıkesir Üniversitesi Sosyal Bilimler Enstitüsü Dergisi, 12(21), 32-45.

[35] Buluç, B. (2009). Sınıf Öğretmenlerinin Algılarına Göre Okul Müdürlerinin Liderlik Stilleri İle Örgütsel Bağlılık Arasındaki İlișki.Educational Administration: Theory and Practice. Vol. 15, Issue 57, pp: 5-34

[36] Koçak, T. (2006). Okul yöneticilerinin dönüşümcü liderlik stilleri ile öğretmenlerin iş doyumu arasındaki ilişki (Ankara il örneği). Yayımlanmış Yüksek Lisans Tezi, Gazi Üniversitesi, Ankara.

[37] Turmuş, E. K. (2005). İş tatmini (iş doyumu) ve sanayi müsteşarlığında bir Uygulama. Yayımlanmış Yüksek Lisans Tezi, Gazi Üniversitesi, Ankara.

[38] Balc1, A. (2016). Sosyal Bilimlerde Araştırma Yöntemler Teknikler İlkeler. 11. Baskı. Ankara.PegemYayıncılık.

[39] Pool, S.W. (1997). The relationship of jop satisfaction with substitutes of leadership, leadership behavior and work motivation. Journal of Psychology, 131(3), 271-282.

[40] Barker, K.J.\& Emery, C.R. (2007). The effect of transactional and transformational leadership styles on the organizational commitment and jop satisfaction of customer contact personel. Journal of Organizational Culture, Communications and Conflict, Vol., January

[41] Taş, S. (2011) "Management Phılosophıes Of Prımary School Principals", Education, 131 (3), pp. 565-579,

[42] Taş, A,; Önder, E. (2010)The Effect of Administrators Leadership Behaviors On Staff Job Satisfaction. Electronic Journal of Social Sciences. Vol.9

[43] Wycoff, M.A. \& Skogan W.G. (1994). The effect of community policing management style on officers"attitudes, Crime \&Delinquency, (40), 371-383.

[44] Barutçugil, İ. (2004). Stratejik insan kaynakları yönetimi. İstanbul: Kariyer Yayıncilık.

[45] Balc1, A. (2003). Örgütsel sosyalleşme: Kuram, strateji ve taktikler. 2. Baskı. Ankara: PegemA Yayıncılık.

[46] Eren, E. (2001). Örgütsel davranış ve yönetim psikolojisi. 
İstanbul: Beta Basım Yayım Dağıtım.

[47] Keser, A. (2006). Çalışma yaşamında motivasyon. İstanbul: Alfa Aktüel Yayınları.

[48] [48] Spector, P.E. (1997). Job satisfaction: application, assessment, cause, and consequences. California: Sage Publications.

[49] MEB (2017). YöneticiAtamaYönetmeliği. 12.4.2017 resmigazete.gov.tr/eskiler/2017/04/2017

[50] Turan, S., Durceylan, B. ve Şişman, M. (2005). Üniversite yöneticilerinin benimsedikleri idari ve kültürel değerler. Manas Üniversitesi Sosyal Bilimler Dergisi, (13), 181-202

[51] Sezgin, F. (2006). İlköğretim okulu öğretmenlerinin bireysel ve örgütsel değerlerinin uyumu. Yayınlanmamış Doktora Tezi, Gazi Üniversitesi, Ankara.

[52] Karip, E.(1998). Dönüşümcü liderlik. Kuram ve Uygulamada Eğitim Yönetimi, 16, 443-465.

[53] Korkmaz, M.(2005). Duyguların ve liderlik stillerinin öğretmenlerin performansı üzerine etkisi. Kuram ve Uygulamada Eğitim Yönetimi, 43, 401-422.

[54] Korkmaz, M. (2006). Okul yöneticilerinin kişilik özellikleri ile liderlik stilleri arasındaki ilişki. Kuram ve Uygulamada Eğitim Yönetimi, 46, 199-226.

[55] Korkmaz, M. (2007). Örgütsel sağlık üzerinde liderlik stillerinin etkisi. Kuram ve Uygulamada Eğitim Yönetimi, 49, 57-91

[56] Yıldırım, C.(2006). Okul müdürlerinin liderlik stillerinin örgütsel sağl1k üzerindeki etkisi (Ankara ili örneği). Yayımlanmamış Yüksek Lisans Tezi. G.Ü, Eğitim Bilimleri Enstitüsü, Ankara

[57] Cemaloğlu, N.(2007). Okul yöneticilerinin liderlik stilleri ile yıldırma arasındaki ilişki. H.Ü Eğitim Fakültesi Dergisi, 33, 77-87.

[58] [59] Cemaloğlu, N.(2007). Okul yöneticilerinin liderlik stillerinin farklı değişkenler açısından incelenmesi. Türk Eğitim Bilimleri Dergisi, 5 (1), 73-112.

[59] Avolio, B.J., Bass, B ve Jung, D.I.(1999). Re-examining the components of transformational and transactional leadership using the multifactor leadership questionnaire. Joumal of Occupational and Organisational Psychology. 72, 441-462

[60] MEB (2017). YöneticiAtamaYönetmeliği. 12.4.2017 resmigazete.gov.tr/eskiler/2017/04/2017

[61] Kaya, Y. K. (1999). Eğitim yönetimi kuram ve Türkiye'deki uygulama. Ankara: Bilim Yayıncılık

[62] Karip, E.(2017). Yönetim Biliminin Alanı Kapsamı.Eğitim Yönetimi Teori, Araştırma ve Uygulama(Edit.Turan S.). Pegem Yay. Ankara

[63] Northouse, P. G. (1994). Organization Behaviour, Orlando: The Dryden Press

[64] Northouse, P. G. (2001). Leadership theory and practice. Thousand Oaks: Sage Publications

[65] Acar, E. (2007). Uzmanlık alanında çalışmanın iş doyumuna etkisi. Paradoks, Ekonomi, Sosyoloji ve Politika Dergisi, y1l $3,(1)$.
[66] Balcı, A., Çınkır, Ş. (2002). Türkiye'de eğitim yöneticilerinin yetiştirilmesi. 21. yüzy1l eğitim yöneticilerinin yetiştirilmesi sempozyumu.Yayın No: 191. Ankara: Ankara Üniversitesi Eğitim Bilimleri Fakültesi

[67] Arslan, H. (2002). Okul müdürlüğünü geliştirme programları. 21. yüzyıl eğitim yöneticilerinin yetiştirilmesi sempozyumu. Yayın No: 191. Ankara: Ankara Üniversitesi Eğitim Bilimleri Fakültesi.

[68] Szilagyi, A. (1990). Organization behaviour, New York:Harper Collins Pub. Co

[69] Akiş T, Y. (2004). Türkiye'nin gerçek liderlik haritası. İstanbul: Melisa Matbaacılık

[70] Kilınç, T. (1997). Durumsallık ötesi liderlik (II), karizmatik liderlik yaklaşımı. 21. Yüzyılda Liderlik Sempozyumu, 5-6 Haziran 1997. İstanbul: Deniz Harp Okulu.

[71] Keçecioğlu, T. (2003). Lider liderlik. İstanbul: Okumuş Adam Yayıncilik.

[72] Tekarslan, E. (1989). Sosyal psikoloji. İstanbul: Filiz Kitapevi.

[73] Chiok, F.L.J. (2001). Leadership behaviours: effeccts on jop satisfaction, productivity. A Service of the National Library of Medicine and the National İnstitutes of Health, S. Jul. 9(4), 191-204.

[74] Suar, D., Tewari, H.R. \& Chaturbedi, K.R. (2006). Subordinates" perception of leardership sttles and their work behaviour. Psychology Developing Societies, (18), 95-114.

[75] Barker, K.J.\& Emery, C.R. (2007). The effect of transactional and transformational leadership styles on the organizational commitment and jop satisfaction of customer contact personel. Journal of Organizational Culture, Communications and Conflict, Vol., January

[76] Bogler, R. (2001). The influence of leadership style on teacher job satisfaction. Educational Administration Quarterly, Vol.. 37, S. 5, ss.662-683.

[77] Yousef, D.A. (2000). Organizational commitment: a mediator of the relationships of leadership behavior with jop satisfaction and performance in a non western country. Journal of Management Psychology, 15(1), 6-28.

[78] Yiğit, A. (2004). Hastanelerde liderlik davranışlarının personel iş doyumuna etkisi belirlemeye yönelik bir alan çalışması. Yayımlanmış yüksek lisans tezi, Gazi Üniversitesi, Ankara.

[79] Mcneese-Smith. D. K. (1991). The Impact of Leadership Behaviors Upon Jop Satisfaction, Productivity and Organizational Commitment of Followers, School of Education

[80] Heller, H.W., Clay, R. \& Perkins, C. (1993). The relationship between teacher jop satisfaction; leadership styles; princippals; teacher administrator relationship; teachers. Journal of School Leadership, 3(1), 74-86.

[81] Gümüşeli, A.İ.(2001). Çağdaş okul müdürünün liderlik alanları. Kuram ve Uygulamada Eğitim Yönetimi, 28, 531-548.

[82] Aydın, İ. (2005). Öğretimde denetim. Ankara: PegemA Yayıncilik. 